\title{
Inquiry-Based Learning Model to Improve Higher Order Thinking Skills
}

\author{
Makrina Tindangen ${ }^{1}$ \\ ${ }^{1}$ Indonesia \\ Correspondence: Makrina Tindangen. E-mail: makrin_tindangen@yahoo.co.id
}

Received: March 15, 2018

Accepted: April 3, 2018

Online Published: June 22, 2018

doi:10.5539/ass.v14n7p39

URL: https://doi.org/10.5539/ass.v14n7p39

\begin{abstract}
This study aims to present ways of implementing inquiry- learning model with the use of scientific reports to improve teachers' understanding and ability on teaching biology at secondary level. The quantitative research method is quasi-experiment design with pre-test and post-test control group. The research instrument for collecting data of students' higher order thinking skills is scoring rubrics for assessing abilities on developing and presenting a scientific report. The instruments for assessing teachers' skills are teacher observation sheets over inquiry-based learning scientific report using an induction method. The research subjects consist of 4 biology teachers and 80 of grade 10 students from Public Secondary School 3 Samarinda.The teachers are all female; while from 80 students, 53 of them are female and the rest 27 are male. The students' age ranges from 16 to 18 years old. The research lasted for 1 month.Analysis of data uses $t$ test, that if $t_{\text {outcome }}$ is higher than $t_{\text {table }}$, the inquiry-based learning model using scientific reports does affect students' higher order thinking skills. Data analysis is composed in tabulation format with several graded categories: inadequate, sufficient, good and excellent. The result of the study is that higher order thinking skills of students are increasing in numbers and more equal compared with classes taught by teachers who did not follow the inquiry-based learning model workshop and presentation. The inquiry-based learning model was applied via preparation and presentations of scientific reports after the students carry out practical activities through the guidance of student activity worksheets.
\end{abstract}

Keywords: inquiry-based learning model, scientific report using an induction method, higher order thinking skills

\section{Background}

The main cause of learning activities problem in the biology subject in Public Secondary School 3 Samarinda is that the practicum activities which are undertaken as part of learning have never been applied as part of a hypothesis proofing activity stage. This stage is also a part of the stages in the inquiry-based learning model.

As a result, the learning experience cannot facilitate the improvement of problem solving skill. If teachers could apply the stages from the inquiry-based learning model, there would be an increase of conceptual understanding and problem-solving skill. The reason for this is because through the stages of inquiry-based learning model, which starts from orientation toward phenomena through observation to the last stage of preparing questions after going through the hypothesis and conclusion, students begin to practice improving their concept understanding through the activities of connecting concepts with the observed phenomena, and to practice improving their higher order thinking skills through problem-solving, problem formulation, hypothesis making, hypothesis proofing, conclusion and new problem formulation (Tindangen, 2007).

Problem-solving skillsare one of the indicators which show that students have reached a particular level of higher order thinking skills, therefore their knowledge as conceptual understanding can be applied to solve problems in daily basis. The problem of biology learning in secondary school is that students do not have the ability to apply their knowledge as conceptual understanding to solve problems in daily basis. A low and uneven level of higher order thinking skills applies to these students. (Azizmalayeri et al., 2012; Fuad, Zubaidah, Mahanal, \& Suarsii, 2017; Makrina, 2007). Biology learning should not stop at concept-forming ability, it should start to change toward a new mindset of higher order thinking skills (masitoh Dwi, Marjono). Driana (2013) stated that according to the result of Programme International Student Assesment (PISA) most Indonesian students could not achieve level 2 on Mathematics and Science therefore they were merely able to apply simple 
calculations on routine procedures and limited scientific procedures and they were not able to apply problem solving skills as a higher level thinking skills.

Problem-solving skills which are part of higher order thinking skills are closely related to students' conceptual understanding. Thus, conceptual understanding and problem-solving skills are about thinking ability. Students will possess this thinking ability as a competence only when teachers are able to facilitate them with the application of suitable learning model. One of effective learning models for improving conceptual understanding and problem solving skill is the inquiry-based learning model with the scientific report using an induction method.

Through using inquiry learning model with saintific report in three main steps: (1) before students carried out their scientific work through the stages of the inquiry-based learning model they determined the title, purpose, problem formulation, hypothesis, and method; (2) they carried out the scientific work according to the method to proof the hypothesis, draw conclusion, and develop new questions; (3) they composed a scientific report and then presented it in group discussions. The phenomena chosen to be the foundation for the scientific work implementation, scientific report, and the presentation were from the students' surrounding environment therefore they would be contextual with students' real experiences. Harmuni (2012) stated that learning through thinking skills ismore meaningful for students. Madhuri, G.V Kantarreddi, V. S and Goteli, L N S P (2012) stated that inquiry based learning model is better than the conventional learning in improving students' higher order thinking skills.

Biology teachers in Public Secondary School 3 Samarinda are facing obstacles in preparing and implementing the inquiry-based learning model with the scientific report using an induction method. That most teachers have not completely understood how to formulate indicators with the learning purpose from the lesson plan has been the indicator that teachers are dealing with problems in preparing the learning tools for the inquiry-based learning model with the scientific report using an induction method. In addition to that, the learning materials are not consistently suitable for the learning purpose yet. In the learning model scope, the applied model is not in accordance with the methods while in the learning scenario part; the stages of the inquiry-based still cannot be seen yet. The evaluation section is often found not in accordance with the learning purpose either.

Based on the problems that teachers and students experience in biology class in Public Secondary School 3 Samarinda City, this research focuses on the implementation of an inquiry-based learning model with the scientific report using an induction methodwhich was applied to the teachers before the research implementation to improve higher order thinking skills Public Secondary School 3 Samarinda City. The focus of this research is a new attempt to overcome students' higher order thinking skills problems and to solve teachers' problems in preparing and applying the tools from the inquiry-based learning model with the scientific report using an induction method in biology class Public Secondary School 3 Samarinda City. Through this research, the teachers are expected to get good understanding and ability to prepare and apply the inquiry-based learning model with the scientific report using an induction method in order to overcome students' low and uneven level of higher order thinking skills.

Most research results merely reported the problems related to students' higher order thinking skillsand they had not reported the attempts to improve teachers' skills in preparing and arranging the lessons. This research appears to report findings related teachers' comprehension and ability before and after going through the modelling activities conducted by the researcher. Furthermore, it also aims to see the impact of inquiry learning method application using the scientific report using an induction methodwhich were applied by teachers of Public Secondary School 3 Samarinda City who joined the modelling activities on the quantity improvement of higher order thinking skills that spread evenly for students of Public Secondary School 3 Samarinda City.

Higher order thinking skills are very important, according to Galbreath (1999) the $21^{\text {st }}$ century is the century of knowledge and a globalization which demands resilience which in this context refers to the higher order thinking skills. High quality human resources with higher order thinking skills like critical thinking and creativity are needed in this knowledgeage (Trilling \& Hood, 1999). Generally, thinking is considered to be a cognitive process (Fudyirtanto, 2002). According to cognitive experts, problem solving is supposed to be the target learning outcome since it one of many creativity forms in thinking which is included in the category of higher order thinking skills (Gagne, 1988).

Based on the obstacles that teachers and students have in Public Secondary School 3 Samarinda City, the research problems are stated as follow:

1. How well do the teachers comprehend, arrange, and apply learning with the inquiry model of scientific report using an induction methodbefore and after they join modelling activities? 
2. Does the application of the inquiry learning method with the scientific report using an induction method which is applied by the teachers affect the quantity of students' higher order thinking skills equally in Public Secondary School 3 Samarinda City?

\section{Research Method}

This research used a descriptive-quantitative research method, (Sugiyono, 2015; Margono, 2010). Observation sheets which comprise stages of the inquiry-based learning model with the scientific report using an induction methodwere used as the research instrument to reveal the data related to teachers' understanding and ability in preparing and applying the inquiry-based learning model. Assessment rubrics which focus on the steps and contents of scientific reports and also scientific report presentation were used as the instruments to measure students' higher order thinking skills. The location of the research was at Public Secondary School 3 Samarinda. The data gathering related to the teachers was conducted before and during the lesson. The data gathering related to the students was conducted during the lesson. There were 4 teachers and 80 grade 10 students from 2 classes as the research subjects. The teachers were all female; while from 80 students, 53 of them were female and the rest 27 were male. The students' age ranged from 16 to 18 years old. The research lasted for 1 monthThe criterion to determine the class was homogeneity. Both classes had an equal average score for the higher order thinking skills before the implementation of the research. Control group pre-test and post-test design was used to measure students' higher order thinking skills. The determination of the treatment group and control group was based on draw. The treatment class consisted of students taught by teachers who joined modelling activities while the control group was taught by teachers who did not join modelling activities. Data analysis related to teachers' understanding and ability presented in tables in categories of: less, sufficient, good, and excellent. The data analysis related to students' higher order thinking skills used t-test.The research procedures are described as follow:

Preparation phase:

1. The researcher prepared observation sheet intrument to assess teachers' comprehension and ability in making learning preparation by using lesson plan as the indicator to see their comprehension and ability in applying the inquiry learning method using the scientific report using an induction methodin the phases of learning as follow: Pre-activity, Main activity and Post activity. The assessment is based on the ability category (inadequate, sufficient, good, excellent)

2. The researcher prepared observation sheet intrument to assess teachers' ability in applying the inquiry learning method with the scientific report using an induction methodwith the indicator of the completeness of the inquiry learning method using scientific report using an induction method in the phases of learning as follow: Pre-activity, Main activity and Post activity. The assessment is based on the ability category (inadequate, sufficient, good, excellent)

3. The researcher prepared the assessment on students' higher order thinking skills which are critical thinking skill and problem solving skill using an asseement rubric focusing on the content of scientific report. It consisted of report arrangement (score: 10), title suitability (score: 10), concept suitability (score: 15), problem formulation suitability (score: 15), hypothesis suitability (score: 15), hypothesis proofing procedure suitability (score: 20), conclusion suitability (score: 15). The total score is 100 . The scoring is done by dividing the observation frequency (students' total score) with the frequency of expectation (total score: 100$)$. Scoring $=\frac{F o}{F e} \times 100$

4. The researcher prepared the research intrument on higher order thinking skills which is used in classroom discussion in a form of scientific report presentation. This assessment covers the presentation skill (25), answering skill with accurate concept (25), time management (10), team's togetherness (15). The scoring is done by dividing the observation frequency (students' total score) with the frequency of expectation (total score:100). Scoring $=\frac{F o}{F e} \times 100$

Implementation phase:

1. Observation sheet instrument to assess teachers' comprehension and ability in planning and applying the inquiry learning model with the scientific report using an induction method which was applied before and after the researcher implemented modelling activities. The modelling activities were initiated by giving the teachers some examples on how to make lesson plans using inquiry learning model with scientific report followed by guiding the teachers in making the lesson plan. Next, the researcher acted as a teacher who implemented the lesson according to the lesson plan using the inquiry learning model with scientific report using an induction method in one parallel class (class X6) which was not selected as the research subject. 
This class was observed by 4 teachers who became the research subjects in modelling activities. After finishing the learning activities, the 4 teachers conducted a discussion with the researcher in order to help the teachers answer their questions on things related to the implementation of inquiry learning model with scientific report using an induction method. The modelling activities were implemented before one of the teachers taught in the treatment class. The teacher was randomlychosen from the 4 teachers who were the subjects in the modelling activities.

2. Assessment intrument on higher order thinking skills through problem solving skills was carried out in form of students' scientific report and scientific report presentation. It was done in the treatment class and was conducted by 1 teacher who joined the modelling activity and 1 teacher who did not join the modelling activity to handle the control class.

3. The subjectsfor the modelling activity were 4 Biology teachers who taught in grade 10 Public Secondary School 3 Samarinda City. All of these teachers were female, approximately over 40 years old.

4. The students subjects were students from 2 classes grade 10 Public Secondary School 3 Samarinda City. Each class consisted of 40 students, therefore the total subjects were 80 students. The crtiterion for choosing these 2 classes was the homogeneity. These classes had similar average score on the higher order thinking skills. Class X1 average score was 43, while class X3 average score was 45 . There were 9 classes parallel of grade 10. Randomly, class X1 was decided to be the treatment class and class X3 to be the control class.

5. The data analysis result related to teachers' comprehension and ability in planning and implementing the learning model were described in a table using the category of inadequate, sufficient, good, and excellent.

6. The data analysis related to the higher order thinking skills in the treatment class and control class using a t-test.

\section{Research Results}

The results related to teachers' understanding and ability in preparing and implementing learning process using an inquiry-based learning model with the scientific report using an induction methodare presented in Table 1.

Table 1. Teachers' understanding and ability in preparing and implementing learning process (Before and after modelling activities conducted by the researcher)

\begin{tabular}{|c|c|c|c|c|}
\hline \multirow{2}{*}{ Observation materials } & \multicolumn{4}{|c|}{ Category } \\
\hline & inadequate & Sufficient & Good & Excellent \\
\hline Learning preparation using inquiry-based model with scientific reports & 2 & & 2 & \\
\hline Learning implementation using inquiry-based model with scientific reports & 2 & & 2 & \\
\hline
\end{tabular}

Source: Research result in 2017

The criteria used tor evaluate teacher's understanding and ability related to the preparation of the utilization of inquiry learning model with scientific report is the aquipment of learning with the preparedness component of the preparation lesson plan, student activity sheet systematic scientific report, assessment instrument.

1. Inadequate if the teacher has a aquipment of learning but does not match the syntax of inquiry learning model with scientific reports.

2. Sufficient if the teacher only has two component aquipment of learning that match the syntax of inquiry learning model with scientific report.

3. Good if the teacher has all the component the aquipment of learning and according to the syntax of inquiry learning model without improvement.

4. Excellent if the teacher has all the component the aquipment of learning and according to the syntax of inquiry learning model without improvement.

The criteria used to evaluate the understanding and skills of teacher releted to the implementation of the ability of teacher using all component of instructional aquipment of learning. The criteria used to evaluate are:

1. Inadequate if the teacher do not use inquiry learning model with scientific report 
2. Sufficient if the teacher in learning does not use all component of instructional aquipment of learning inquiry model with scientific report.

3. Good if the teacher applay all component aquipment of learning inquiry model scientific reports with tittle improvement

4. Excellent if the teacher applay all component aquipment of learning inquiry model with scientific reports without improvement.

The t-test results related to students' higher order thinking skills in treatment group and control group show that $t_{\text {count }}$ is larger than $t_{\text {table }}$ where $t_{\text {count }}=2,60$ and $t_{\text {table }}=1,84$.

Table 2. Data of students possessing higher order thinking skills before and after the learning with an inquiry-based learning model with the scientific report using an induction method.

\begin{tabular}{llll}
\hline No & Group/Class & Before Learning & After Learning \\
\hline & Control Class & $\begin{array}{l}5 \text { students were indicated in the category of } \\
\text { possessing higher order thinking skills }\end{array}$ & $\begin{array}{l}11 \text { students were indicated in the category } \\
\text { of possessing higher order thinking skills }\end{array}$ \\
& $\begin{array}{l}\text { Treatment } \\
\text { Class }\end{array}$ & possessing higher order thinking skills & $\begin{array}{l}30 \text { students were indicated in the category } \\
\text { of possessing higher order thinking skills }\end{array}$ \\
\hline
\end{tabular}

Source: Research result in 2017

The criteria used to evaluate students problem solving skills through aspect of students ability to define topics, formulate goals, problem-solving producers, construct hypotheses, problem-solving methods, and scientific report presentation skills. If all these aspect are filled with students then they are in the category of high-level thinking ability.

\section{Discussion}

The results related to teachers' learning preparation and implementation show that the teachers who joined the modelling activities obtained good results in preparing the learning instruments using the inquiry-based learning model with the scientific report using an induction method. Meanwhile, the teachers who did not join the modelling activities obtained inadequate results. Apparently, the results are related with the implementation of the inquiry-based learning model. The teachers who joined the modelling activities obtained good results while those who did not obtained inadequate results.

The t-test results show that the implementation of the inquiry-based learning model has affected the $10^{\text {th }}$ grade students' higher order thinking skills in Public Secondary School 3 Samarinda. The results show the outcome of students' thinking ability from the treatment report using an induction methodwere higher and more equal among the students when compared to the control group in which the teachers did not implement the inquiry-based learning model with the scientific report using an induction method. Table 2 shows that there is a difference in numbers of students who possessed higher order thinking skills in control class and treatment class before and after the implementation of an inquiry-based learning model with the scientific report using an induction method.This means that students' higher order thinking skills are related with the inquiry-based learning model implemented in the learning. The results of this research match to the research results from Madhuri et al (2012) which shows inquiry based approach learning is better than that in the convensional approach in improving students' higher order thinking skills. It is also supported by the research result from Masitoh at al (2017) that found the guided inquiry learning model gives significant effects on critical thinking skills.

The learning activities in the treatment class, which applied the stages of the inquiry-based learning model with the scientific report using an induction method,were implemented in three main steps: (1) before students carried out their scientific work through the stages of the inquiry-based learning model they determined the title, purpose, problem formulation, hypothesis, and method to solve the problem; (2) they carried out the scientific work according to the method to proof the hypothesis, draw conclusion, and develop new questions; (3) they composed a scientific report and then presented it in group discussions. The phenomena chosen to be the foundation for the scientific work implementation, scientific report, and the presentation were from the students' surrounding environment therefore they would be contextual with students' real experiences.

The results from this research indicate that scientific work, which is followed by scientific report and presentation and is adjusted to students' real life has become the defining factor in achieving higher order thinking skills. The development of higher order thinking skills potentials can be done through critical thinking 
skill in problem solving skill (Fascione, 2013), (Azizmaleyari et al., 2012). The results of this research support the findings from Proulx (2004) which states that identifying and solving problems in real life improves the higher order thinking skills. According to Lawson (2000) learning science using hipothetico-deductive reasoning can promote higher order thinking skills. Learning which involves problem analysis, hypothesis formulation, variable manipulation, designing, and conducting investigations can develop students' higher order thinking skills. According to Dahar (1989) and Ausubel (1968) children have curiousity and constantly want to understand things around them. This curiousity can actively motivate children to build layouts in their brains. When children are always challenged by problems around them and trained to solve them, their mental would be broader and more abstract.

It is important for teachers to implement activities referring to the steps of scientific methods and these activities should be contextual to students' experiences in the learning process as it is put forward by Costa and Presseisen (1985) who categorise higher order thinking skills into problem solving, decision making, critical thinking and creative thinking. According to experts, these thinking skills can be achieved through contextual learning. According to Proulx (2004) the stages of higher order thinking skills are similar to the stages of scientific methods implementation. Therefore, implementing scientific method can practice higher order thinking skills. Contextual learning train students to solve problems in real life since they are involved in the practice of problem solving, thus they are also trained to develop higher order thinking skills (Nurhadi, 2002).

The results from the treatment group show that the scientific work and the scientific report which are relevant to students' surrounding can support higher order thinking skills. According to Gagne (1985) rules play an important role in problem solving. It is impossible for students to get all rules needed in every situation. Concepts and rules must be synthesized into new complex forms, students will be able to overcome new situations and problems. Problem solving is a human activity which combines existing concepts and rules and not a generic skill (Dahar, 1989; Lawson, 2000).

In this research, after students from the treatment group finished their scientific work, they continued to write scientific reports to be presented in class discussion. According to Proulx (2004) scientific method implementation which is followed by classroom discussion and debates in science class can help students focus their higher order thinking skills. To help the students, teachers can provide activities where students can give and defend their opinion as well as answer the questions from their classmates or the follow-up questions from the teacher in order to further develop their higher order thinking skills.

A good conceptual understanding will support higher order thinking skills namely problem solving in this case. Students will enhance their problem solving skill when they have a conceptual understanding of the problem they are dealing with. According to Gagne (1985) a concept is the building block in thinking. It means that concept is the basic foundation in thinking and without concept, thinking process will not occur. Based on this, if improving higher order thinking skills is the purpose then improving conceptual understanding is the first step to be taken.

To improve conceptual understanding and problem solving skill, teachers need to facilitate learning using suitable learning strategies to support understanding and skills. One of the strategies that can be used to support the conceptual understanding and problem solving skills is the inquiry-based learning model. Through this inquiry-based learning, students are guided to improve their conceptual understanding through activities which are parts of the stages of inquiry-based learning (Dewi \& Sadia, 2013). The stages of inquiry-based learning begins with an orientation toward phenomena through observation, problem formulation, hypothesis formulation, conclusion, new questions. If carefully examined, each of the stages of inquiry-based learning has already facilitated conceptual understanding and problem-solving skill related to concepts being learned, in this case a biology lesson at secondary school level (Tindangen, 2016).

In this research the treatment group implemented the stages of inquiry-based learning model with the guidance of students' worksheet. It began with natural phenomena observation where students in groups observed their school surroundings to know more about photosynthesis. Next, the students wrote the problem formulation like whether or not mango trees go through photosynthesis which followed by hypothesis formulation. Next, the students in their groups proved the hypothesis through the steps listed in the worksheet. Furthermore, after proving the hypothesis students in their groups collected the results and drew conclusion which stated whether or not mango trees photosynthesise based on their findings. Afterward, the students formulated further questions, for example: Why do mango trees cannot photosynthesise when there is too much rain or when it is too dry; Howcanmango trees be preserved so that they can carry out a photosynthesis process? What is the relation between photosynthesis and the survival of living beings? Teachers as facilitator would help students face 
difficulties.

The next step after finished implementing the steps from inquiry-based learning model in the previous paragraph, was for students to write their scientific reports systematically in group (introduction, purpose, procedure, result, and conclusion). The introduction contained the specific phenomena of plants in surrounding area, e.g. their failure in photosynthesis process. The example of purpose is to maintain the viability of living things through the sustainability of the photosynthesis process. The procedure maintains the continuity of the photosynthesis process. The results were obtained after completing the procedure. The conclusion was drawn referring to the purpose. In the next step, students presented their report in class discussions. Teachers facilitated all of the process from the implementation of stages in inquiry-based learning model through to the students' scientific report presentation (Tindangen, 2016). Scientific report and the scientfic report presentation were scored using an assessment rubric as mentioned in the procedure phase.

Jasen et al. (2014) stated that many educators fail since they merely ask questions on the content to know students' thinking skills. Therefore, questions which really measure higher order thinking skills must be prepared. The assessment rubric used in this research to measure students' higher order thinking skills is an assessment form that accomodates the statement.

\section{Conclusion}

Based on the results of the research, there are two conclusions that can be drawn:

1. The results show that the learning model implemented in this research help to improve teachers' understanding and ability in planning implementing the inquiry-based learning model with the scientific report using an induction methodin biology lesson in Public Secondary School 3 Samarinda.

2. The results show that the implementation of the inquiry-based learning model with the scientific report using an induction methodin biology lesson in Public Secondary School 3 Samarinda has improved the quality of students' higher order thinking skills equally.

Research results implication

The result of this research shows contribution toward:

1. Progress on teachers' knowledge especially in the way it improves teachers' comprehensin and ability in planning and implementing the inquiry learning model with the scientific report using an induction methodand also in the way it assesess students' higher order thinking skills through students' scientific report and scientific report presentation.

2. Teaching implementation in a way that there is teachers' better comprehension and ability in planning and implementing the inquiry learning model with the scientific report using an induction methodas a solution to higher order thinking skills problems in secondary school level.

3. Education policy makers. The modelling acticities which were conducted in this research can be adpted by Education policy makers in teachers' quality improvement programs related to their professional and pedagogic competence.

\section{Acknowledgments}

Thanks to Director General of Research and Technology Research and Development, Director of Research and Community Service of Research, Technology and Higher Education which has facilitated in the form of research funding for 3 years. This year is the third year, funding the last year through ongoing grant fund contract research graduate research in 2017

\section{References}

Ausubel, D. P. (1968). Educational Psychology: A Cognitive View. New York: Holt, Rinehart and Winston, Inc.

Azzizmaleyari, K., Mirsahan Jafari, E., Sharif, M., Asgari, M., \& Omidi, M. (2012). The Impact of guided inquiry methods of teaching on the critical thinking of high school student. Journal of Education and Practice, 3(10), 1-7.

Costa, A. L., \& Presseisen, B. Z. (1985). Glossary of Thinking Skills. In A. L. Costa (Ed.), Developing Minds: A Resource Book for Teaching Thinking. Alexandria: ASCD, 303312.

Dahar, R.W. (1989). Teori-teori Belajar. Jakarta: Erlangga.

Depdikbud. (2013). Kurikulum, Standar Kompetensi Mata Pelajaran Biologi Sekolah Menengah Atas dan Madrasah Aliyah. Jakarta: Depdiknas. 
Dewi, K., \& Sadia, I. D. (2013). Pengembangan perangkat pembelajaran IPA terpadu dengan settinginkuiri terbimbing untuk meningkatkan pemahaman konsep dan kinerja Ilmiah siswa. E-journal from Natural Science Education Study Program, Ganesha University of Education.

Driana, E. (2013). Menyikapi hasil PISA 2012. Kompas 6 Diperoleh 18 Februari 2014.

Fascione. (2013). Critical thinking: What it is and whay it counts. Calofornia measured Reasonand the California Academic Press. Diperoleh 10 Oktober 2017.

Fuad, N. M., Zubaidah, S., Manahal, S., \& Suarsin. (2017). Improving jnior high school' critical thinking skills based on test three deferent models of learning. International Journal of Instruction, 10(1), 101-106. https://doi.org/10.12973/iji.2017.1017a

Fudyrtanto, K. R. (2002). Psikologi Pendidikan. Yogyakarta: Penerbit Global Pustaka Utama.

Gagne, E. D. (1985). The Cognitive Psychology of School Learning. Boston: Little, Brown.

Galbreath, J. (1999). Preparing the $21^{\text {th }}$ Century Worker: The Link between Computer-Based Technology and Future Skills Sets. Educational Technology, 14-22.

Hamruni. (2012). Strategi pembelajaran. Yogyakarta: Insan Madan.

Jansen, J. L., \& Mdaniel, M. A., Woodard, S. M., \& Kummer, T. A. (2014). Teaching to the test or testing to Teach: Exams requiring higher order thinking skills Encourage Greater Conceptual Understanding. Educational Psychology Review, 26(2), 307-329. https://doi.org/10.1007/s10648-013-9248-9

Lawson, A. E. (2000). The Generality of Hypotetico-Deductive Reasoning; Making Scientific Thinking Explicit. The American Biology Teacher, 62(7), 482-495. https://doi.org/10.1662/0002-7685(2000)062[0482:TGOHD $\mathrm{R}] 2.0 . \mathrm{CO} ; 2$

Lee, A. (1999). Transfer as a Measure of Intellectual Functioning. Unpublished Manuscript, USA.

Nurhadi. (2002). Pendekatan Kontekstual. Malang. Penerbit Universitas Negeri Malang.

Proulx, G. (2004). Integrating Scientivic Method and Critical Thinking. The American Biology Teacher, 66(1), 26-33. https://doi.org/10.2307/4451613

Tindangen, M. (2016). Pengembangan Perangkat Pembelajaran Berbasis Model Inkuiri untuk Meningkatkan Kemampuan Berpikir Tingkat Tinggi Siswa SMP dan SMA, Laporan Hasil Penelitian Hibah Pasca, Lembaga Penelitian Universitas Mulawarman (Unpublished).

Trilling, B., \& Hood, P. (1999). Learning, Technology and Education Reform in The Knowledge Age. Educational Technology, 5-18.

\section{Copyrights}

Copyright for this article is retained by the author(s), with first publication rights granted to the journal.

This is an open-access article distributed under the terms and conditions of the Creative Commons Attribution license (http://creativecommons.org/licenses/by/4.0/). 